\title{
Evaluation of Blood Transfusion Complications in Patients Undergoing Surgery
}

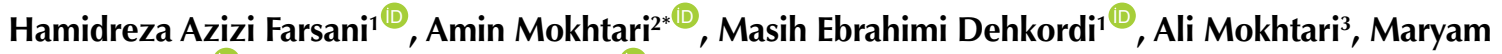 \\ Mardanshahi $^{{ }^{\circledR}}$, Donya Sheibani Tehrani ${ }^{\circledR}$
}

'Department of Anesthesiology, Shohadaye Tajrish Hospital, Shahid Beheshti University of Medical Sciences,

Tehran, Iran

${ }^{2}$ Shahid Beheshti University of Medical Sciences, Tehran, Iran

${ }^{3}$ Department of Neurosurgery, Isfahan University of Medical Sciences, Isfahan, Iran

${ }^{4}$ Department of IT, Shahid Beheshti University, Tehran, Iran

\section{*Correspondence to}

Amin Mokhtari, MD, Shahid Beheshti

University of Medical Sciences,

Tehran, Iran.

Tel: +989104971330

Email: aminmokhtari111273@gmail. com

Received August 8, 2020

Accepted October 18, 2020

Published online December 30, 2020

\section{Abstract}

Introduction: Patients undergoing surgery may need transfusion of blood products for a variety of reasons. Therefore, this study aimed to determine the incidence of blood transfusion complications in patients undergoing surgery.

Methods: The present study was performed as a cross-sectional study in 2020 at Shohadaye Tajrish Hospital in Tehran, Iran. A total of 1132 patients who had complications during surgery upon transfusion of blood and blood products from 2015 to 2020 were included in the census. To collect information, a checklist, including patients' information, the type of product, and types of complications was used. SPSS software version 21 was used for data analysis.

Results: In this study, $99.7 \%$ of the complications were acute, and in $91.1 \%$ of the cases, the severity of complications was mild. Of the confirmed complications, $46.4 \%$ were allergic reactions, and $43.8 \%$ were reported as non-hemolytic febrile reactions. A total of $91.1 \%$ of patients completely recovered after the onset of the complication, $6.2 \%$ had a partial disability, $0.4 \%$ had severe disability, and $0.3 \%$ died.

Conclusion: The results showed that most patients had acute complications in terms of the type of complication and mild in terms of the severity, thus a completely regular program is recommended to control side effects related to blood and blood products transfusion.

Keywords: Blood transfusion, Transfusion reaction, Complications, Patients, Surgery
Please cite this article as follows: Azizi Farsani H, Mokhtari A, Ebrahimi Dehkordi M, Mardanshahi M, Sheibani Tehrani D. Evaluation of blood transfusion complications in patients undergoing surgery. Int J Basic Sci Med. 2020;5(4):136141. doi: $10.34172 /$ ijbms.2020.24

\section{Introduction}

Blood transfusion is an acute medical intervention that is usually a quick and short-term treatment in the face of life-threatening conditions of patients or stabilization of dangerous health conditions. $^{1,2}$ In recent decades, the development of technology in the science of blood transfusion has been a continuous and growing trend to be able to initially increase the safety of blood transfusion for recipients. ${ }^{3}$ However, blood transfusion may still cause some complications and dangerous conditions. ${ }^{4}$ Many of these risk complications are associated with the presence of allogeneic white blood cells in injected blood products. ${ }^{5}$ Although over years little attention has been paid to the presence of leukocytes in blood products, today access to appropriate techniques for the removal and reduction of white blood cells in blood products, along with improvement of the effectiveness have significantly reduced some common complications of blood transfusion. ${ }^{6}$ These improvements include a reduction in the frequency and severity of transient blood transfusion reactions, a significant reduction in the risk of transmitting the cytomegalovirus infection, and the possibility of some other diseases transmitted by donor leukocytes such as Creutzfeldt-Jakob disease, a decrease in the prevalence of alloimmune platelet resistance, as well as in the risk of mortality or organ dysfunction in recipients,

(C) 2020 The Author(s); Published by Zabol University of Medical Sciences. This is an open-access article distributed under the terms of the Creative Commons Attribution License (http://creativecommons.org/licenses/by/4.0), which permits unrestricted use, distribution, and reproduction in any medium, provided the original work is properly cited. 
especially in patients who are candidates for cardiac surgery. ${ }^{6}$

Studies have shown that septicemia, an acute complication, and respiratory injury due to blood transfusion, which are acute complications, are the causes of $4 \%-42 \%$ of 189 deaths due to blood transfusions. ${ }^{7,8}$ Any sign and symptom that is observed during or shortly after blood transfusion should be considered as a complication of the injection unless proven otherwise. The severity of a blood transfusion reaction may not be appreciable due to the patient's clinical symptoms. For example, acute hemolytic reaction may be from life-threatening to a mild symptomatic complication. ${ }^{9,10}$

Therefore, any symptom following blood or blood products transfusion should be considered potentially threatening and be timely identified health professionals. Blood transfusion reactions may be acute or delayed. Acute reactions occur during or within the first 24 hours of injection, but delayed reactions occur days, weeks, and even years later. ${ }^{11,12}$

Acute blood complications include allergy, acute hemolytic complication, septicemia, tracheal, anaphylactic shock, and acute pulmonary edema. Due to the fact that acute complications of blood transfusion are more common and fatal than blood-borne viral infections, much attention is paid to this issue today. ${ }^{13,14}$

Due to the high prevalence of blood transfusion complications and related mortality and morbidity, this study was performed to determine the complications of blood transfusion in patients undergoing surgery at Shohadaye Tajrish Hospital in Tehran, Iran.

\section{Materials and Methods}

This was a cross-sectional retrospective study conducted in Shohadaye Tajrish hospital affiliated to Shahid Beheshti University of Medical Sciences in Tehran, Iran, in 2020. The records of all patients who underwent blood and blood product transfusions during surgery and also had transfusion complications. Overall, 1132 records were included in the study by census from 2015 to 2020 . Inclusion criteria include undergoing surgery and the need for blood transfusions and blood products during surgery. Exclusion criteria include not having transfusion complications and incomplete archived data.

Data was collected using a checklist to record the patient's demographic information, disease history, types of products leading to the complication and complete information of products, body temperature, heart rate, respiration rate, blood pressure, crossmatch status, direct antiglobulin test (DAT) result, and antibody screening, and complications, and finally the patient's fate.

Qualitative variables were expressed by frequency and percentage and quantitative variables by mean and standard deviation. After checking and confirming the normality of the distribution of quantitative data, paired sample $t$ test and McNemar test were employed to evaluate the difference between quantitative and qualitative variables before and after transfusion. Frequency tables and statistical tests were performed in SPSS software version 21 . The significance level of statistical tests was considered $P<0.05$.

\section{Results}

In this study, the files of 1132 patients were examined. Regarding gender, $37.8 \%$ of patients in this study were men, and $62.2 \%$ were women. Seventy percent of the cases had over 40 years old, and only $3.5 \%$ were under the age of 10 years. The mean age of the patients was 51.9 \pm 21.23 years in the age range of 1 to 96 years.

Overall, $44.8 \%$ of patients had a history of antibiotic use, $22.1 \%$ had a history of hypertension, $20.4 \%$ had a history of heart diseases, and $49.5 \%$ had a history of transfusion in less than three months. Forty-five point three percent of women had experienced a history of pregnancy more than three months ago (Table 1).

The results of this study showed that $72 \%$ of the complications were caused by RBC (packed cell) product, $9 \%$ by fresh frozen plasma (FFP) , $6.9 \%$ by random donor platelet (RDP) and 5.7\% by Leuko-reduced RBCs. Eightypoint six percent of the product type had a complication related to $\mathrm{RBC}$, and in $64.5 \%$ of cases, the injection of the product after observing the complication was stopped. The patient's condition in $97.6 \%$ of cases was under no anesthesia. The average age of the injected product was 39.32 days, which is in the age range of 0 to 716 days. The average time interval between the beginning of the injection and the onset of the complication was 99.03 minutes in the time range of 1 to 720 minutes. The average volume of injection of the product until the occurrence of the complication was $146.96 \mathrm{~mL}$ in the volume range of 1 to $500 \mathrm{~mL}$ (Table 2).

The results of this study show that body temperature, heart rate, and respiration rate before injection and after the complication were significantly different $(P<0.05)$. Mean body temperature, heart rate, and respiration rate

Table 1. Patients' records

\begin{tabular}{|c|c|c|c|}
\hline & & Number & Percent \\
\hline \multirow{2}{*}{ Pregnancy history } & Yes, less than 3 months ago & 45 & 6.5 \\
\hline & Yes, more than 3 months ago & 319 & 45.3 \\
\hline \multicolumn{2}{|c|}{ History of high blood pressure } & 201 & 22.1 \\
\hline \multicolumn{2}{|c|}{ History of heart disease } & 231 & 20.4 \\
\hline \multicolumn{2}{|l|}{ History of lung disease } & 80 & 7.1 \\
\hline \multicolumn{2}{|c|}{ History of immunodeficiency } & 90 & 8 \\
\hline \multicolumn{2}{|c|}{ History of kidney disease } & 93 & 8.2 \\
\hline \multicolumn{2}{|l|}{ History of allergies } & 88 & 7.8 \\
\hline \multicolumn{2}{|l|}{ History of liver disease } & 44 & 3.9 \\
\hline \multirow{2}{*}{$\begin{array}{l}\text { History of blood } \\
\text { transfusion }\end{array}$} & Yes, less than three months & 558 & 49.5 \\
\hline & Yes, more than three months & 119 & 10.5 \\
\hline \multicolumn{2}{|l|}{ History of antibiotic use } & 618 & 54.6 \\
\hline
\end{tabular}


Table 2. Summary of Products' Information Leading to Complications

\begin{tabular}{|c|c|c|c|c|}
\hline & & & Number & Percent \\
\hline & Whole & & 3 & 0.3 \\
\hline & RBC (p & cell) & 815 & 72 \\
\hline & Leuko- & ed RBC & 64 & 5.7 \\
\hline & Washe & & 11 & 1 \\
\hline & $\begin{array}{l}\text { Washe } \\
\text { RBC }\end{array}$ & ko-reduced & 11 & 1 \\
\hline The type of the product & RDP & & 78 & 6.9 \\
\hline leading to complications & SDP & & 18 & 1.6 \\
\hline & Pooled & & 2 & 0.2 \\
\hline & Irradiat & atelet & 12 & 1.1 \\
\hline & Childre & lood bag & 1 & 0.1 \\
\hline & Irradiat & & 8 & 0.7 \\
\hline & FFP & & 104 & 9 \\
\hline & Cryopr & ate & 5 & 0.4 \\
\hline & RBC & & 912 & 80.6 \\
\hline & Platele & & 110 & 9.7 \\
\hline 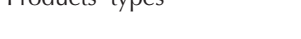 & FFP & & 109 & 9.6 \\
\hline & Whole & & 1 & 0.1 \\
\hline & $\mathrm{A}+$ & & 353 & 31.2 \\
\hline & A- & & 25 & 2.2 \\
\hline & $\mathrm{B}+$ & & 245 & 21.6 \\
\hline Products' $\mathrm{ABO}$ and $\mathrm{Rh}$ & B- & & 27 & 2.4 \\
\hline blood groups & $\mathrm{O}+$ & & 369 & 32.6 \\
\hline & O- & & 33 & 2.9 \\
\hline & $\mathrm{AB}+$ & & 74 & 6.5 \\
\hline & AB- & & 6 & 0.6 \\
\hline Was product injection & Yes & & 729 & 64.5 \\
\hline occurrence? & No & & 402 & 35.5 \\
\hline tis th o dition & $\begin{array}{l}\text { Under } \\
\text { anesth }\end{array}$ & & 23 & 2 \\
\hline during transfusion & Local a & esia & 4 & 0.4 \\
\hline & None & & 1105 & 97.6 \\
\hline & & Mean & SD & Min-Max \\
\hline Product age (days) & & 39.32 & 91.95 & $0-716$ \\
\hline $\begin{array}{l}\text { Interval from the start of tran } \\
\text { to the occurrence of compli } \\
\text { (min) }\end{array}$ & $\begin{array}{l}\text { sfusion } \\
\text { cation }\end{array}$ & 99.03 & 91.42 & $1-720$ \\
\hline $\begin{array}{l}\text { Approximate volume of the } \\
\text { injected product until the on } \\
\text { complication }(\mathrm{mL})\end{array}$ & set of & 146.96 & 90.57 & $1-500$ \\
\hline
\end{tabular}

increased significantly after injection and complication. There was no significant difference in systolic and diastolic blood pressures before the injection and after complication $(P<0.05)$. The results also showed that in $99 \%$ of cases, crossmatch before and after the onset of the complication was compatible $(P<0.05)$. In $99.4 \%$ of cases, DAT test, and in $98.3 \%$ of cases, antibody screening before product injection and after complications were negative $(P<0.05$, Table 3$)$.
Complications reported in this study show that $99.7 \%$ of complications were acute and $91.1 \%$ were mild (grade 1 ), and regarding the types of complications, $55.2 \%$ and $30.5 \%$ of the cases were allergic and non-febrile reactions, respectively. Of the confirmed complications of blood transfusion, $46.4 \%$ reported allergic reactions and $43.8 \%$ reported non-hemolytic febrile reactions. Ninety-threepoint one percent of patients fully recovered after the onset of the complication, $6.2 \%$ had a partial disability, $0.4 \%$ had severe disability, and only $0.3 \%$ died (Table 4 ).

Transfusion side effects in patients included $40.5 \%$ chills, $30.6 \%$ fever, $25.3 \%$ urticaria, $21.3 \%$ pruritus, $20.6 \%$ skin redness, $18.6 \%$ restlessness, and $16 \%$ tachycardia (Table 5).

\section{Discussion}

Blood transfusion is an acute medical intervention and a rapid treatment in the face of life-threatening conditions and stabilization of dangerous health conditions. However, blood transfusions may still cause some dangerous complications. According to studies, more than $20 \%$ of injections lead to various complications in the recipient of blood and its products. ${ }^{15,16}$ Reactions that occur within the first 24 hours after a blood transfusion are considered premature reactions and occur in $1 \%$ to $3 \%$ of transfusions. ${ }^{17}$ The findings of the present study showed that on average, $99.7 \%$ of the recipients had acute complications 99 minutes after blood transfusion. RBC (packed cell) product with $72 \%$ triggered the most and pediatric blood bag product with $0.1 \%$ had the least complications. Also, blood group O + with $(32.6 \%)$ had the highest and blood group AB- with (0.6\%) had the lowest associations with these complications. The average time interval between the onset of the complication from the time of injection was 99 minutes. In the study of Asvadi-Kermani et $a{ }^{18}{ }^{18}$ the incidence of these early reactions was confirmed in $98 \%$ of cases.

Allergic reactions are common transfusion complications and often occur mildly in 1 to $3 \%$ of cases after injection and are usually accompanied by skin manifestations such as itching, skin rash, and flushing. ${ }^{19}$ Allergies usually occur following the injection of plasma products. Allergy, which is one of the most common and acute complications following blood transfusion occurred in $46.4 \%$ of our patients, which is higher compared to the statistics reported by other researchers like Pandey and $\operatorname{Vyas}^{20}(1 \%-5 \%)$, and Teimuri et all ${ }^{12}(0.3 \%)$. In general, research results indicate that red blood cells are generally responsible for allergic reactions in patients. ${ }^{19,21}$

One of the most common early reactions to blood transfusion is the non-hemolytic complication of fever. ${ }^{22}$ Non-hemolytic fever typically occurs following the injection of cellular products such as packed red blood cells, whole blood, and platelets, and rarely occurs with plasma products. ${ }^{22-24}$ According to studies, the highest rate of non-hemolytic fever is due to platelet injection (30\%) 
Table 3. Summary of clinical and laboratory indicators before injection and after complication

\begin{tabular}{|c|c|c|c|c|}
\hline & & Mean & SD & $P$ Value $^{\mathrm{a}}$ \\
\hline \multirow{2}{*}{ Body temperature } & Before injecting the product & 36.96 & 0.42 & \multirow{2}{*}{0.001} \\
\hline & After the onset of the complication & 37.55 & 1.28 & \\
\hline \multirow{2}{*}{ Heart rate } & Before injecting the product & 87.34 & 28.02 & \multirow{2}{*}{0.001} \\
\hline & After the onset of the complication & 95.18 & 21.67 & \\
\hline \multirow{2}{*}{ Systolic blood pressure } & Before injecting the product & 113.48 & 34.56 & \multirow{2}{*}{0.125} \\
\hline & After the onset of the complication & 132.48 & 416.24 & \\
\hline \multirow{2}{*}{ Diastolic blood pressure } & Before injecting the product & 70.46 & 30.37 & \multirow{2}{*}{0.081} \\
\hline & After the onset of the complication & 72.05 & 15.09 & \\
\hline \multirow{2}{*}{ Number of breaths } & Before injecting the product & 19.34 & 10.12 & \multirow{2}{*}{0.001} \\
\hline & After the onset of the complication & 21.1012 .61 & & \\
\hline & & \multicolumn{2}{|c|}{ After the Onset of the Complication } & \multirow{2}{*}{$P$ Value $^{b}$} \\
\hline & Before injecting the product & Compatible & Incompatible & \\
\hline \multirow{3}{*}{ Crossmatch } & Compatible & $906(99 \%)$ & $6(0.7 \%)$ & \multirow{2}{*}{0.031} \\
\hline & Incompatible & $0(0 \%)$ & $3(0.3 \%)$ & \\
\hline & & Positive & Negative & \\
\hline \multirow{3}{*}{ DAT test } & Positive & $2(0.3 \%)$ & $0(0 \%)$ & \multirow{2}{*}{0.501} \\
\hline & Negative & $2(0.3 \%)$ & $634(99.4 \%)$ & \\
\hline & & Positive & Negative & \\
\hline \multirow{2}{*}{ Antibody screening } & Positive & $9(1.5 \%)$ & $0(0 \%)$ & \multirow{2}{*}{0.981} \\
\hline & Negative & $1(0.2 \%)$ & $578(98.3 \%)$ & \\
\hline
\end{tabular}

a Paired sample $t$ test, ${ }^{\mathrm{b}} \mathrm{McNemar}$ test.

Table 4. Types of complications and patients' outcomes

\begin{tabular}{|c|c|c|c|}
\hline & & Number & Percent \\
\hline \multirow{2}{*}{$\begin{array}{l}\text { Type of } \\
\text { complication }\end{array}$} & Acute & 1129 & 99.7 \\
\hline & Chronic & 3 & 0.3 \\
\hline \multirow{3}{*}{$\begin{array}{l}\text { Severity of the } \\
\text { complication }\end{array}$} & Mild (Grade 1) & 1031 & 91.1 \\
\hline & Severe (Grade 2) & 94 & 8.3 \\
\hline & $\begin{array}{l}\text { Life-threatening (Grade } 3 \\
\text { like shock) }\end{array}$ & 7 & 0.6 \\
\hline \multirow{12}{*}{$\begin{array}{l}\text { Type of } \\
\text { complication } \\
\text { confirmed } \\
\text { (blood transition) }\end{array}$} & FNHTR & 496 & 43.8 \\
\hline & Allergic reaction & 525 & 46.4 \\
\hline & TAD & 9 & 0.8 \\
\hline & TRALI & 2 & 0.2 \\
\hline & TACO & 4 & 0.4 \\
\hline & TA-GVHD & 1 & 0.1 \\
\hline & $\begin{array}{l}\text { Hypotension related to } \\
\text { transfusion }\end{array}$ & 3 & 0.3 \\
\hline & delayed HTR & 1 & 0.1 \\
\hline & nonimmune hemolysis & 42 & 3.7 \\
\hline & immune hemolysis (ABO) & 7 & 0.6 \\
\hline & $\begin{array}{l}\text { immune hemolysis } \\
\text { (alloantibody) }\end{array}$ & 38 & 3.4 \\
\hline & other reaction & 4 & 0.4 \\
\hline \multirow{4}{*}{ Clinical status } & Completely improved & 1053 & 93.1 \\
\hline & Minor or brief disability & 70 & 6.2 \\
\hline & $\begin{array}{l}\text { Severe disability or } \\
\text { permanent disability }\end{array}$ & 5 & 0.4 \\
\hline & Death & 3 & 0.3 \\
\hline
\end{tabular}

compared to other blood products, while packed red blood cells, which are the most used blood product, have the lowest rate of non-hemolytic fever (0.5\%-6\%). ${ }^{12,25,26}$ In this study, the prevalence of non-hemolytic fever was $43.8 \%$, which is higher than other reports. On the other hand, most cases of non-hemolytic fever occurred following the injection of packed red blood cells. This result is inconsistent with other studies in which most of these complications are related to the injection of platelet units.

In the present study, the most common side effects in patients included chills (40.5\%), fever (30.6\%), urticaria (25.3\%), and pruritus (21.3\%). In their descriptive study, Bodaghkhan et $\mathrm{a}^{11}$ evaluated 57902 hospitalized patients undergoing transfusion over two years for acute complications of transfusion and stated that $0.08 \%$ of patients had acute transfusion complications. Out of 52 patients, 25 had a fever, 15 had itching and redness of the skin, 15 had a skin rash, 9 had back pain, 5 had hypotension, 5 had shortness of breath, 1 had chest pain, 1 had hematuria, and 1 patient had cold sweating. The most common acute complication observed after blood transfusion was fever, and its prevalence was reported to be $0.04 \%$, which was in line with our study and lower compared to international statistics.

Najafi Ghezeljeh and Kalhor $^{27}$ in their review on 15 articles found that survival during the first 30 days and also during the first year after heart surgery among 
Table 5. Side effects caused by transfusion

\begin{tabular}{|c|c|c|}
\hline & Number & Percent \\
\hline Fever & 417 & 36.8 \\
\hline Chills & 458 & 40.5 \\
\hline Back pain & 46 & 4.1 \\
\hline Headache & 48 & 4.2 \\
\hline Chest pain & 58 & 5.1 \\
\hline Stomach ache & 35 & 3.1 \\
\hline Urinary incontinence & 3 & 0.3 \\
\hline Decreased urination & 8 & 0.7 \\
\hline Discoloration of urine & 50 & 4.4 \\
\hline Restlessness & 211 & 18.6 \\
\hline Feeling sick & 113 & 10 \\
\hline Hot flashes & 114 & 10.1 \\
\hline Itching & 241 & 21.3 \\
\hline Wheals & 286 & 25.3 \\
\hline Redness of the skin & 233 & 20.6 \\
\hline Stridor & 3 & 0.3 \\
\hline Wheeze & 13 & 1.1 \\
\hline Tachypnea & 81 & 7.2 \\
\hline Bleeding & 14 & 1.2 \\
\hline Rhonchus & 13 & 1.1 \\
\hline Nausea & 86 & 7.6 \\
\hline Vomit & 47 & 4.2 \\
\hline Lower blood pressure & 29 & 2.6 \\
\hline Increased blood pressure & 98 & 8.7 \\
\hline Bradycardia & 7 & 0.6 \\
\hline Tachycardia & 181 & 16 \\
\hline
\end{tabular}

patients who had blood transfusion was significantly lower than patients without blood transfusion. The incidence of death in short- and long-term after surgery was significantly higher among patients with blood transfusion than patients without blood transfusion. Complications such as atrial fibrillation, infection, pneumonia, and stroke were also significantly higher in patients with blood transfusion. Meanwhile, Salimi et al. ${ }^{28}$ examining 1261 patients who received 3880 units of blood products stated that the most common complaints were cold (22.5\%), pruritus (20.1\%), and chills (18.1\%). Acute hemolytic reactions, fever reactions, and allergic reactions were $0.52,6.2$, and 1.11 per 1000 injections, respectively. They concluded that despite improved blood purification techniques, acute transfusion reactions could lead to significant mortality, which was consistent with the results of this study.

\section{Conclusion}

Careful attention should be paid by physicians, nurses, and midwives to the early signs and symptoms of an acute reaction to blood and its products transfusion. This can be important in preventing more adverse consequences following transfusion. Hospitals can also manage complications by creating a regular schedule for blood and blood product transfusions.

\section{Ethical Approval}

This study was approved by Shahid Beheshti University of Medical Sciences Ethics Committee with the code of IR.SBMU.REC.1398.863. All patients' records remained confidential to the researcher.

\section{Conflict of Interest Disclosure}

The authors declare there is no conflict of interests.

\section{Authors' Contributions}

All authors contributed equally to this study.

\section{References}

1. Bhaskar B, Dulhunty J, Mullany DV, Fraser JF. Impact of blood product transfusion on short and long-term survival after cardiac surgery: more evidence. Ann Thorac Surg. 2012;94(2):460-467. doi:10.1016/j.athoracsur.2012.04.005

2. Borhany $\mathrm{M}$, Anwar $\mathrm{N}$, Tariq $\mathrm{H}$, et al. Acute blood transfusion reactions in a tertiary care hospital in Pakistanan initiative towards haemovigilance. Transfus Med. 2019;29(4):275-278. doi:10.1111/tme.12541

3. Carson JL, Noveck H, Berlin JA, Gould SA. Mortality and morbidity in patients with very low postoperative $\mathrm{Hb}$ levels who decline blood transfusion. Transfusion. 2002;42(7):812-818. doi:10.1046/j.1537-2995.2002.00123.x

4. Junio J, Gamponia R. Post-operative outcomes of CABG patients given blood transfusion based on Society of Thoracic Surgeons Guidelines on blood transfusion. Phil Heart Center J. 2012;16:47-54.

5. Paone G, Likosky DS, Brewer R, et al. Transfusion of 1 and 2 units of red blood cells is associated with increased morbidity and mortality. Ann Thorac Surg. 2014;97(1):8794. doi:10.1016/j.athoracsur.2013.07.020

6. Loor G, Li L, Sabik JF 3rd, Rajeswaran J, Blackstone EH, Koch CG. Nadir hematocrit during cardiopulmonary bypass: end-organ dysfunction and mortality. J Thorac Cardiovasc Surg. 2012;144(3):654-662.e654. doi:10.1016/j. jtcvs.2012.03.058

7. Kleinman S. Transfusion-transmitted infection risk from blood components and plasma derivatives. In: Simon TL. Dzik WH, Snyder EL, Stowell CP, Strauss RG, eds. Rossi's Principles of Transfusion Medicine. 3rd ed. Philadelphia, PA: Lippincott Williams \& Wilkins; 2002:706-707.

8. McCullough J. Transfusion Medicine Paper: John Wiley \& Sons; 2016.

9. Sazama K. Reports of 355 transfusion-associated deaths: 1976 through 1985. Transfusion. 1990;30(7):583-590. doi:10.1046/j.1537-2995.1990.30790385515.x

10. Azizi S, Tabary SZ, Soleimani A. Prevalence of acute blood transfusion reactions in Mazandaran Heart Center, 
Sari, Iran, 2010-2012. Med Arch. 2014;68(2):137-139. doi:10.5455/medarh.2014.68.137-139

11. Bodaghkhan F, Ramzi M, Vazirian SR, et al. The prevalence of acute blood transfusion reactions in Nemazee hospital. Sci J Iran Blood Transfus Organ. 2014;11(3):247-251. [Persian].

12. Teimuri H, Imani F, Maghsudlu M, Kia Daliri K, Fallah Tafti M. Prevalence of acute blood transfusion reactions in 11 hospitals of Tehran and Mazandaran province. Sci J Iran Blood Transfus Organ. 2007;4(1):19-24. [Persian].

13. Simon TL, McCullough J, Snyder EL, Solheim BG, Strauss RG. Rossi's Principles of Transfusion Medicine. John Wiley \& Sons; 2016.

14. Rudmann SV. Textbook of Blood Banking and Transfusion Medicine. Elsevier Health Sciences; 2005.

15. Beutler E, Williams WJ, Lichtman $\mathrm{M}$, et al. Williams Hematology. McGraw-Hill Professional; 2006.

16. Handin RI, Lux SE, Stossel TP. Blood: Principles and Practice of Hematology. Lippincott Williams \& Wilkins; 2003.

17. Hankins J, Lonsway RA, Hedrick C, Perdue M. Infusion Therapy in Clinical Practice: An Evidence-Based Approach. Saunders; 2001:394-395.

18. Asvadi-Kermani I, Evazie Ziaeei J, Nikanfar AR, et al. Blood transfusion acute reactions in patients of Shahid Ghazi hospital. Sci J Iran Blood Transfus Organ. 2006;2(6):215221. [Persian].

19. Domen RE, Hoeltge GA. Allergic transfusion reactions: an evaluation of 273 consecutive reactions. Arch Pathol Lab Med. 2003;127(3):316-320. doi:10.1043/00039985(2003)127<0316:atr>2.0.co;2

20. Pandey S, Vyas GN. Adverse effects of plasma transfusion. Transfusion. 2012;52 Suppl 1:65S-79S. doi:10.1111/j.1537- 2995.2012.03663.x

21. Silliman CC, Boshkov LK, Mehdizadehkashi Z, et al. Transfusion-related acute lung injury: epidemiology and a prospective analysis of etiologic factors. Blood. 2003;101(2):454-462. doi:10.1182/blood-2002-03-0958

22. Dy SM. Measuring the quality of palliative care and supportive oncology: principles and practice. J Support Oncol. 2013;11(4):160-164. doi:10.12788/j.suponc.0017

23. Shimada E, Tadokoro K, Watanabe Y, et al. Anaphylactic transfusion reactions in haptoglobin-deficient patients with IgE and IgG haptoglobin antibodies. Transfusion. 2002;42(6):766-773. doi:10.1046/j.1537-2995.2002.00117.x

24. Hoffman R, Benz EJ Jr, Silberstein LE, Heslop H, Anastasi J, Weitz J. Hematology: Basic Principles and Practice. Elsevier Health Sciences; 2013.

25. Goodman C, Chan S, Collins P, Haught R, Chen YJ. Ensuring blood safety and availability in the US: technological advances, costs, and challenges to payment--final report. Transfusion. 2003;43(8 Suppl):3S-46S. doi:10.1046/j.15372995.43.8s.2.x

26. Azarkeivan A, Ahmadi MH, Hajibeigy B, Gharebaghian A, Shabehpour Z, Maghsoodlu M. Evaluation of transfusion reactions in Thalassemic patients referred to the Tehran adult Thalassemia clinic. J Adv Med Biomed Res. 2008;16(62):57-66. [Persian].

27. Najafi Ghezeljeh T, Kalhor L. Clinical outcomes of blood transfusion after coronary artery bypass graft surgery: a review of literature. Iranian Journal of Cardiovascular Nursing. 2015;4(3):64-71. [Persian].

28. Salimi SA, Feizi A, Vanabadi N. Incidence rate of acute reactions in transfusion of blood and its products prepared by Urmia Blood Refinery Center. Advances in Nursing \& Midwifery. 2009;19(66):8-13. [Persian]. 